\title{
The Need to Act: Incest as a Crime Given Low Priority-A View with India as an Example
}

\author{
Peter Choate $^{1, *(\mathbb{D})}$ and Radha Sharan ${ }^{2}$ \\ 1 Social Work, Mount Royal University, Calgary, AB T3E 6K6, Canada \\ 2 Tata Institute of Social Sciences, Mumbai 40008, India; newsharan44@gmail.com \\ * Correspondence: pchoate@mtroyal.ca; Tel.: +1-403-4405-008
}

Citation: Choate, Peter, and Radha Sharan. 2021. The Need to Act: Incest as a Crime Given Low Priority-A View with India as an Example. Social Sciences 10: 142. https://doi.org/ 10.3390/socsci10040142

Academic Editor: Nigel Parton

Received: 19 February 2021

Accepted: 7 April 2021

Published: 16 April 2021

Publisher's Note: MDPI stays neutral with regard to jurisdictional claims in published maps and institutional affiliations.

Copyright: (c) 2021 by the authors. Licensee MDPI, Basel, Switzerland. This article is an open access article distributed under the terms and conditions of the Creative Commons Attribution (CC BY) license (https:// creativecommons.org/licenses/by/ $4.0 /)$.

\begin{abstract}
Background: Incest is a form of sexual activity that occurs within family or kinship systems It is prohibited by religion and law in most countries as well as by social mores or taboos. Data from various parts of the world indicate, however, that it appears to be a relatively common event, although there is reason to believe that the actual frequency is unknown. Most available data focus upon children as victims, although we note that incest also occurs between adult family members. Methods: A systematic review was performed using PRISMA guidelines. With a focus upon India, the search tools of Academic Search Complete, Google Scholar and PUBMED were used to identify articles that legally defined incest; frequency; barriers to disclosure; the dynamics of incest and social norms. Results: The available data were very limited, making a systematic review unachievable within the narrow confines of incest. Conclusions: The literature is sparse. This led to a discussion of definitional issues; barriers to disclosure; and challenges with measuring the problem of incest and the impact of social norms. Questions of law and efforts at reform were also considered. The article considers what steps might be appropriate.
\end{abstract}

Keywords: incest; child sexual abuse; child maltreatment; incest and law; criminal law and incest; India

\section{Introduction}

Child sexual abuse (CSA) is described by the World Health Organization (WHO) as the "involvement of a child in sexual activity that he or she does not fully comprehend, is unable to give informed consent to, or for which the child is not developmentally prepared, or else that violates the laws of social taboos of society" (World Health Organization WHO, p. vii). CSA is considered to be pervasive and widely under-reported in India (Carson et al. 2013). A survey by the Government of India suggests that the rates may be as high as one in two children (Juyal et al. 2017). Generally, CSA is thought to be underreported (Juyal et al. 2017).

Poddar and Mukherjee (2020) describe the range of CSA activities as broad and can include touching, molestation, sodomy, exhibitionism, pornography and cybersexual acts. They also note that CSA has long-term adverse effects for victims.

In this article, we seek to explore the socio-legal context of incest as a way to understand how social work and the law may need to rethink their intersections with victims and perpetrators of incest. We begin by exploring the challenges with defining the term incest. This matters greatly as it determines what behaviours are included and excluded from societal responses. This leads to challenges related to measuring the frequency of incestual activity within a society. While India is not alone in experiencing incest, we use this jurisdiction to consider a number of problems which countries grapple with around the world. We look at how research in policy and practice can improve a societal response. We conclude with recommendations regarding the place of practitioners in changing the conversations in society about how social work and the law can respond to incest cases.

In this review, we sought to ascertain the extent to which the problem of incest is defined, measured and appropriately subject to criminal sanctions using India as an 
example. We then sought to determine the application of the law to the protection of a person from incest.

\section{Method}

The PRISMA guidelines were originally used (Moher et al. 2009). Using the search tools of Academic Search Complete, Google Scholar and PUBMED, we sought to identify articles that legally defined incest; frequency; barriers to disclosure; and the dynamics of incest and social norms. The focus was upon India serving as an example, although care was taken to consider extant literature in Canada from the vantage point of enhancing the search, definition and parameters.

Search terms included: incest in India; incest + India; incest law India; incest law Canada; incest frequency + India; incest frequency + Canada; defining incest; defining incest + India; defining incest + Canada; intrafamilial child sexual abuse + India; and sibling sexual abuse + India. Unlike Choudhry et al. (2018), we focused solely upon the issue of incest as opposed to broader incidents of sexual assault and child abuse. Exclusion criteria were articles related to moral philosophy (although they were useful for definitional purposes), historical, literature, medical forensic processes and data such as family violence that did not specifically address incest.

Inclusion criteria was a focus upon incest; published in English; focused upon India; published in peer review journals; not duplicate reporting; and published between 2000 and 2020.

\section{Results}

Perhaps the most striking result was that the literature that measures incest is remarkably small when looked at as a problem distinct from child sexual abuse, physical abuse, or other forms of neglect. Canada, for example, reports sexual abuse along with physical abuse or sexual abuse that is perpertrated by a variety of people with whom there may or may not have been an incestual relationship.

There was not a coherent collection of datasets or articles to draw upon for prevalence.

The search yielded 842 possible articles, but only two articles were identified as pertaining specifically to the subject of incest, India and the law (Sharangpani 2018). It is not that the topic was not inferred in other publications, but rather that they were imbedded within a larger child sexual abuse context. An example of such a paper is the work of Kacker and Kumar (2008), which fell outside of our search period but who noted incest within the larger consideration of child abuse and neglect (CAN) in India. They reported that, of their sample, one in three girls who described being sexually abused indicated that a perpetrator was a relative. One interesting conclusion of the work of Carson et al. (2013) is that their review of earlier work noted a limited literature, but that intrafamilial sexual abuse was across socio-economic groupings.

Given the lack of academic publications, some data for this article were drawn from general media sources.

\subsection{Definitional Confusion}

Definitional confusion occurs across cultures, societies, professions and legal jurisdictions. In our review of the literature, it was clear that multiple approaches existed that drew from social, cultural and contextual norms.

The Oxford Dictionary of Public Health (Porta and Last 2018) defines incest as:

Sexual intimacy between close blood relations; i.e., siblings, parent and child, uncle-niece, aunt-nephew. Incest has long been taboo in most societies and is the subject of myths, legends, and literature; e.g., Sophocles' Oedipus trilogy. In some communities it has been empirically associated with a high frequency of abnormal offspring. It was customary and approved in the families of the pharaohs in the Egyptian dynastic period. If an underage person is one of the partners, it is criminal sexual abuse. If incest leads to pregnancy and childbirth, the risk of genetic defects in the offspring is greater than in mating among 
unrelated couples, especially if both partners carry a recessive gene for a deleterious inherited characteristic. The prevalence of incest varies according to cultural values. In Western societies it is often identified in criminal proceedings in cases of sexual abuse, but its true prevalence is unknown. In the Middle East and the Indian subcontinent, as many as 50\% of marriages are of first cousins and uncle-niece pairs, and there appear to have been no major adverse genetic effects on health as a result.

Incest has two common definitions. The first includes sexual actions between a parent, step and adoptive parent or guardian and an underage child. It is a subcategory of child sexual abuse which is a broader category including both intra- and extra-familial offenders. Yildirim et al. (2014) report that father-daughter incest is the most common version, followed by brother to sister versions. Incest also includes sexual activities between adult members of a family who are not in a partnership (e.g., husband and wife) relationship. This can include adult children, close relatives and people who are blood ties with each other (Green 2019). All incest involves intra-familial perpetrators including those who are tied by blood and those tied by contractual relationships (Sagarin 1977). Thus, it is important to acknowledge that incest has a variety of definitions, some legal, some based on cultural tradition, some drawn from religion and some drawn from social restrictions.

There is a broad literature on why incest is subject to prohibition, which ranges from work in psychodynamic traditions, to genetic, sociological, religious and historical needs for affinal relationships across kinship systems (Bittles 2012).

Bixler (1983) adds more context in which we see that incest has layers of meaning such as the specific relationship between the individuals; age differential; degree of sexual activity; consent; and duration of the sexual relationship. Some researchers offer a more limited view, such as the requirement for sexual intercourse (Bixler 1983).

Our literature review suggests that incest is not typically addressed in measurement data as distinct. Green (2019) notes that the most common form involves an adult and a child. Incest involving children is often categorized within child sexual abuse and that which occurs between adults is seen in various forms of sexual assault, such as rape.

There is evidence that incest occurs in many societies and cultures (Green 2019). The vast majority of cases are never disclosed, making it difficult to determine the true frequency. Cromer and Goldsmith (2010) suggest that it is a fairly common form of child abuse, which is typically the major category that incest is categorized within (Putnam 2003). These same authors note that incest creates long-term problems for its victims that stretch well into adulthood and affect mental and physical health as well as the capacity for healthy adult relationships (Putnam 2003). Green (2019) indicates that the data on frequency of incest involving adults are poor.

As Clayton et al. (2018) describe, the broader category of child sexual abuse (CSA) is drawn as a point of focus as it encompasses the full range of sexual abuse that a child can experience. It recognizes the wide range of possible intra- and extrafamilial perpetrators, including family friends, teachers, coaches, religious figures, as well as strangers. For children, the definition revolves around the inability to offer informed consent. Younger children lack the emotional and moral development to be able to judge and form intent to offer consent. Even adolescent children can lack capacity, either through insufficient development, difficulty in judging what is and is not appropriate, as well as power structures in family systems that prohibit safely denying engaging in the sexual activity (World Health Organization WHO).

In a leading 2005 case in Canada, the Supreme Court of Canada (R v G.R 2005) noted that incest may include consensual behaviors, but that:

"Proof of consent makes no difference to the result" (para. 17). The court rejected the argument that consensual "recreational' sexual activity with blood relations should be legalized and constitutionally protected" because the prohibition against incest has nothing to do with consent but is directed to preserving the integrity of the family by avoiding the confusion in roles that would result from incestuous sex... there is a "heavy 
physiological penalty imposed by inbreeding", that is, the sharply increased risk of genetic defects in the children born of incestuous relationships. [pp. 443-44]

The prohibition against incest is also associated with "protection of vulnerable family members" (p. 445). Writing for the court, Roscoe J.A. concluded that incest, whether consensual or non-consensual, is unacceptable, incomprehensible and repugnant to the vast majority of people, and has been for centuries in many cultures and countries. [p. 445]

A further challenge of definition is determining what is sexual activity. A recent High Court decision in India suggests that touching a clothed child may not be sexual assault. In the decision Satish $v$ State of Maharashtra (Satish 2020) Justice Pushpa Ganediwala of the Nagpur Bench of the Bombay High Court noted:

"Considering the stringent nature of punishment provided for the offence (under the India Protection of Children from Sexual Offences Act 2012, also known as POCSO), in the opinion of this Court, stricter proof and serious allegation. The act of pressing of breast of the child aged 12 years, in the absence of any specific detail as to whether the top was removed or whether he insert his hand inside top and pressed her breast, would not fall in the definition of 'sexual assault'" (Satish 2020).

Thus, society, law and family systems need to have a sense of exactly where the boundary is drawn, although the boundaries may well vary depending upon where that boundary is being drawn from. This becomes further complicated with the ever-increasing use of media, the internet and other social platforms where video and photography are distributed. Whether the perpetrator is an incestuous connection or not, access to victims does not require physical presence.

For our purposes, we define incest between adults in accordance with Jeaash (2020) as sexual activity between family members who are prohibited to marry due to their close kinship even though consent may be offered. For defining incest involving children, we refer to Kluft (2011) who outlines various forms of sexual activity between people with varying levels of relatedness which may include blood relations, those related by marriage, including stepparents and step siblings. The lack of ability to consent is vital to understanding childhood incestual victimization (World Health Organization WHO).

\subsection{Barriers to Disclosure}

Before considering challenges of measurement, we note that there are many barriers to disclosure which can make measuring the size of the problem in any society extremely difficult. Indeed, barriers tend to outweigh facilitators for reporting (Alaggia et al. 2019). Generally, disclosure of CSA (and by definition incest) is traumatic, and thus the prevalence is much greater than reported. Keeping the secret is the more common experience. Lemaigre et al. (2017), in a systematic review, found particular barriers including limited support for the discloser, perceived negative consequences, along with feelings such as shame, guilt and self-blame. Tillman et al. (2010), in a review of African American sexual assault survivors, also added barriers of racism, stigma and unsupportive responses. Alaggia et al. (2019) adds that cultural and societal attitudes can also be barriers, although they may also act as facilitators. Alaggia et al. (2019) notes that many victims may have tried to disclose at various times in their lives. Her work shows that incest victims live in a complex ecological environment where schools, peers, and community as well as familial connections can act as facilitators or barriers. One author (PC) notes that, within direct clinical work with incest victims, prior attempts to disclose were common, although often subtle or met with disapproval, as the cost of hearing and acting upon the disclosure was perceived as high by the receiver of the report. This could include facing other forms of sexual or physical violence that may have occurred, family break up or loss of position within a culture or community. An interesting further barrier to disclosure can be the place of the non-offending members in the family who may also feel emotional burdens for failing to protect the victims (Bittles 2012). 


\subsection{Measuring the Problem}

It is difficult to measure a problem with populations where three barriers exist. The first is definitional, as noted above. Related to this is legal, in that states must determine in law what is being prohibited. The second, measurement problems, arise from the barriers to disclosure. These occur in families where, even if it is disclosed to one person, it may still be held in secret to avoid bringing shame or fracturing of the family, as noted above. The third problem is the willingness of police to accept a complaint, which we suggest later in this paper is a problem in India, although not unique to India.

The available frequency data are very challenging as a basis of determining what is occurring, between whom and how frequently. Definition is a major barrier, as is the reality that incest is likely disclosed in only a small minority of cases (Yildirim et al. 2014). Gekoski et al. (2016), in a rapid evidence assessment, found that there is a wide variation in prevalence estimates due to the population studied, definitions and data reliability, with estimates of incestual activity that range from $5 \%$ to $62 \%$. In essence, there seems to be a lack of good frequency data (Choudhry et al. 2018). In a large meta-analysis of intrafamilial and extrafamilial child sexual offenders, Seto et al. (2015) found that there were some significant differences between the two groups. Better understanding of such differences can help to better understand the scope and nature of the problem. For example, they found that intrafamilial offenders had more childhood difficulties including the likelihood of their own sexual abuse victimization in childhood, family abuse and neglect and poor attachment with parents, particularly the mother.

Stoltenborgh et al. (2011) found that up to one third of CSA cases were perpetrated by a family member, with fathers and step-fathers being the most common perpetrator.

Kloppen et al. (2016) illustrate that the research data results can be so broad as to not really assist in determining the size of the problem. Their study of CSA in Nordic countries illustrates the challenges. The main inconsistencies were: demarcation of the victim's age at the time of abuse, categorization of sexually abusive behavior, inclusion of peer abuse, and the number and wording of the survey items. (p. 40). Ballantine (2012) states that sibling based incest is rarely reported.

Kaur et al. (2019) posit that, in India, child rape is very common, although true numbers are unknown. However, they examined 100 reported cases, finding that the majority of victims were under the age of fourteen. Choudhry et al. (2018) in a survey of available data in India, also confirm that the perpetrator was often known to the child victim, with a family member being quite common.

Our review of available data indicates that the size of the problem of incest in India, is not well known. Data are often hidden within child sexual abuse reports, but we emphasize that while incest includes the sexual abuse of a child, it is a particular form and needs to be addressed very specifically. Family is meant to be a safe place for a child to grow, but incest takes that away and, as noted above, acts as the pathway into lifelong struggles. Seto et al. (2015) also show that intrafamilial CSA has many unique characteristics, suggesting that measuring the problem also means understanding the true nature of the problem. Extrafamilial and intrafamilial CSA should not be folded into one folder, but rather subject to separate understanding and measurement efforts.

\subsection{The Dynamics of Incest}

The research tells us that there are at least three reasons why incest is seen as taboo. The first is related to the possibility of genetic abnormalities arising from close relational parentage by people who share proximal genetic makeup. The second often cited reason is the negative impact that incest has on the safe foundation of the family unit and its capacity to stay and function together. This is also related to the power dynamics that emerge in the family when incest occurs. The perpetrator holds a position of power over the victim as well as forcing the hand of those who do not agree with the behaviour. The latter family members are forced into acquiescence in order keep the family together. This also links to the question of consent. It is generally accepted that a child cannot consent to sexual 
activity, but can there be valid consent within a family system power structure? Others also argue that there may be times when sexual relationships between consanguine descendants might be acceptable. These are highly philosophical discussions that go beyond the scope of this paper (Alaggia et al. 2019; Kluft 2011).

\subsection{Social Norms}

Incest is socially prohibited, with deep roots in history as communal or ingroup restrictions. Society found ways to determine which sort of sexual relationships were considered acceptable and which should be prohibited. The latter may occur by law or by some other form of social control (Tillman et al. 2010).

The social pressure to not engage in incest acts as a barrier when that moral value is seen as accepted and overriding. When the cues are accurately read that a potential sexual partner is outside of the social norms, then they act as a powerful deterrent (Lieberman and Smith 2012). There can be many cues that a person is a close relative, such as the way that the person is treated by known kin, physical similarities and proximity within a community. Family itself can also signal who is and is not permitted to be connected to in a sexual manner, although this may be for reasons other than kinship, such as cultural or community competition.

The social pressure can also rest on moral prescriptions laid out by societal structures, such as law, criminal enforcement and child protection, which may then be reinforced community or kinship forces (Yildirim et al. 2014).

The socio-biological taboo against incest in India, at least towards children, exists by prohibiting male relatives including fathers, uncles, brothers as well as other male relatives from engaging in sexual activity (Irudayam et al. 2011). However, when social norms are ineffective, as they will be at times in all societies, then the law, as the representative of society, acts as the basis for social norm restrictions.

Marriage in India, being a personal issue, is dealt with by both personal laws (India, Hindu Marriage Act 1955); (India, The Muslim Personal Law (Shariat) Application Act (1937)); (India, Christian Marriage Act 1872) and central law (India, Special Marriage Act 1954). Marriage is prohibited in certain degrees of proximal relationships. Marriage cannot be conducted between two people who are connected by blood, marriage or adoption, whereas some religions allow marriage between two cousins (Pandey 2017). In terms of social structure, a woman in India is often presumed to be in a submissive role and have limited options in life. Indian women are trusted to choose to live in accordance with traditional values rather than their own happiness. In an interview, Deepa Nayaran described women in India being groped by males as a normalized activity, which is no longer traumatic. The interview quotes her saying, "I call the way girls are raised 'fear training,' literally, training girls to become fearful. It is training based on no and don't. No, you can't do this. No, you can't do that." (Doshi 2018).

\section{A Question of Law}

\subsection{Matters from Indian Law}

The Indian legal system has no laws which mention incest specifically as an offence (Tiwary 2020) This absence has been recognized before, but little has changed (Namhata 2020; Tiwary 2020). Data provided by the National Crime Records Bureau (NCRB) show that sexual offences against women and children are increasing every year. Given that the law does not describe it as a crime, there are no available data to define how often incest occurs. The POCSO (India, Protection of Children from Sexual Offences 2012) protects children to an extent from sexual abuse that is committed by family and close relatives, but there is a legal gap with the POCSO Act (India, Protection of Children from Sexual Offences 2012) as it does not define a special procedure to provide the victim with a remedy in case incest occurs in the household. There are social implications that require attention. In a family system where poverty, familial supports, lack of housing alternatives, banishment 
from the family and community may all be problematic if incest is disclosed, the costs to the victim and those who support the victim may be very high.

Article 15(3) of the Constitution of India (1950) states: "Nothing in this article shall prevent the State from making any special provision for women and children."

It provides all of the 30 States, 9 Union Territories and the Central Government with a special power to create special laws for the protection and promotion of children and women. Article 39 (f) of the Constitution of India (1950) states: "that children are given opportunities and facilities to develop in a healthy manner and in conditions of freedom and dignity and that childhood and youth are protected against exploitation and against moral and material abandonment".

This enforces an obligation on the state to create policies that provide children with opportunities and facilities to develop with dignity and in an exploitation free environment which promotes healthy upbringing of the child. If one reads the Constitution of India (1950) with the United Nations Conventions on the Right of the Child (1990), Article 19, which states that the State should take all measures to protect children from sexual abuse by a parent, legal guardian or any other person who is trusted with the care of the child. The Convention was ratified by the Indian government in November 1992.

\subsection{India Law and CSA}

Sexual exploitation against children is one of the leading and under-reported offences in India. In a survey conducted by the Sakshi Non-Governmental Organization, it was reported that every second child has experienced sexual abuse at least once before the age of 18 , and $90 \%$ of these sexual abuses are at the hands of family members or someone known to them (Ravi 2020). The COVID-19 lockdown period, which was enforced from 22 March 2020 to 25 September 2020, showed that children are not protected within their own homes and from their own families, as multiple newspapers reported incestuous rape almost every other day (Das 2020). In 2019 (NCRB 2019) there were 24,672 cases of sexual penetrative assault $[39, \mathrm{s.4}]$ and sexual assault $[39, \mathrm{~s} .5]$ in which a child was the victim. Of that number, $2153(8.72 \%)$ of the offences were committed by a member of the family of the victim, which is $78.95 \%$ more than in 2018 (NCRB 2018), and a shocking increase of $747.56 \%$ since 2010. The data reported by the National Bureau of Criminal Records show an increase in the cases of sexual violence and exploitation committed against children at the hands of their own family (See Figure 1).

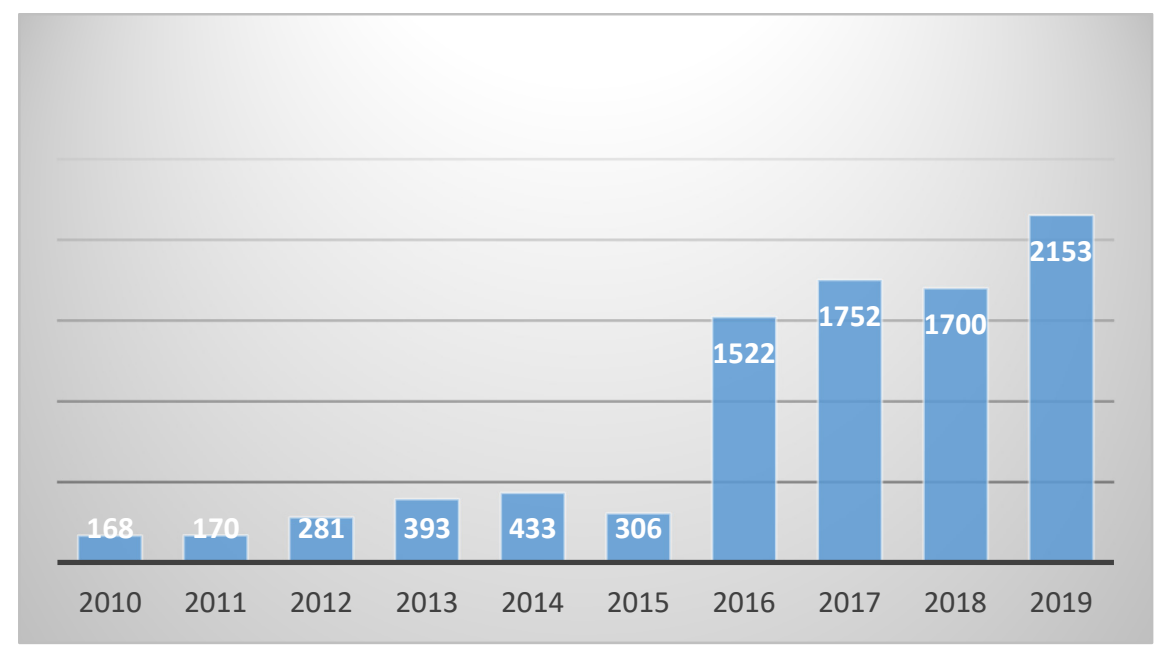

Figure 1. Reported cases of incest in india against children. The data after 2016 are shown under the POCSO Act, (2012) (Source: https:/ / ncrb.gov.in/access accesed on 6 March 2021). These data suggest that $P O C S O$ has been influential increasing the number of cases, albeit that this still represents a likely tip of the iceberg. 
POCSO (2012) was enacted and enforced in India with the aim to protect children from sexual assault, sexual harassment and to stop the use of children in pornography. It also provided for the establishment of special courts for a speedy trial. The preamble of the POCSO (2012) states that it was put in place in furtherance of United Nations Conventions on the Right of the Child (1990), but POCSO (India, Protection of Children from Sexual Offences 2012) fails to create a safe environment for children who are sexually assaulted by their family members, as one can agree that such children need special protection and care from the law and society at large.

As an aside, we are not aware of an effective child protection system that exists across India that would protect the child from the perpetrator. In some cases (although it is not known how many), a child may be removed from the family and placed in a child care institution. This may well not be a better environment for the child, and also places further burdens on the child by being removed the from their family while the alleged perpetrator stays within the family. Choudhry et al. (2018) also note that children suffer negative consequences over their lifetimes, which removal from the family, we would argue, would exacerbate. Furthermore, the rates of sexual abuse of children in child care institutions in India are reported to be quite high (Human Rights Watch 2013).

Section 5 (n) of POCSO (India, Protection of Children from Sexual Offences 2012) holds any penetrative sexual activity by a relative of the child through blood, marriage, adoption or any other position where the person is charged with the care of the child to be deemed as an aggravated penetrative sexual assault which shall be punished with rigorous imprisonment of not less than 10 years but may be extended to imprisonment for life and also liable to a fine. Section 7 (n) of POCSO (India, Protection of Children from Sexual Offences 2012) holds a person who is related to the child by blood, marriage, adoption or a person who is charged with the care of person, if caught having committed sexual touching or fondling of a child, as being guilty of aggravated sexual assault, which shall be punished with imprisonment for no less than five years and which may be extended to seven years. The High Court (HC) case referred to earlier (Satish 2020) shows that this offers limited protection against certain forms of incest, as these laws are open to interpretation.

It can be said the government made an honest attempt to put forth the idea that that sexual abuse of a child can occur in homes and in the care of a trusted person, but the Act fails in multiple areas to work in the best interest of the child. The POCSO (India, Protection of Children from Sexual Offences 2012) has no time limit for filing a complaint or the need for any specific injury to be present on the body of victim arising from the sexual assault. Many times, judges have interpreted the Act in such a way that the mere absence of injury or delay in the filing of the first instance report (FIR) was held to be grounds for false implications.

Section 19 of POCSO (2012) gives discretionary power to the local police officer to make arrangements for a child if the police officer thinks that the child needs special care and protection, which might include a shelter home or hospital.

An argument against this discretionary power is that each and every child who is sexually assaulted by a family member will require special care and protection. The impact of this trauma is long-standing (World Health Organization WHO) The police officer charged with investigating an incest case requires special skills and training (Ardulov et al. 2018). Such training is not common among front line officers (Azzopardi et al. 2019). The presence of trained, relationally based disclosure management in CSA is a facilitator (Satish 2020) - whether this is true with incest is unknown but probable.

It is valuable to also consider that when a child has disclosed abuse and the report has been accepted, the child may be subject to various examinations including physical and forensic, as well as police, mental health and other professional interviews (Seth and Srivastava 2017). For children, the process can be quite traumatizing and places them within loyalty binds between the family and the accused (Greydannus and Merrick 2017). These binds are relational-father figure-daughter; between siblings; mother-son; and between other family members (Greydannus and Merrick 2017). There is no doubt that 
girls are more vulnerable and more often victimized (Choudhry et al. 2018) which may link to social norms in India related to the lesser value of girls (Sharangpani 2018). This can also lead to girls being more vulnerable to disclosure and subsequent legal processes.

Section 24 of POCSO (India, Protection of Children from Sexual Offences 2012) says the statement of the child should be recorded as far as practical by a female police officer not below the rank of a sub-inspector. The guidelines issued by the Ministry of Home Affairs state that the FIR should be filed by female officers (Ministry of Home Affairs 2020). However, female officers constitute only 8.89 per cent of the police force (Tripathi 2020). Thus, representation of women is very low and not available in each and every police station, which can lead to a delay in recording the statement of the child.

A special court has been established under the s.28 of POCSO (India, Protection of Children from Sexual Offences 2012) in each district of India. As per the information released by the High Courts, there are approximately 2.4 lakh $(2,400,000)$ cases pending in all the special courts as of December 2019 (Business Standard 2020). The pendency of cases demotivates a victim to report a case, as the fear of being in court for a long time acts as a reminder of the crime that was perpertrated against the victim. The delay in the process is one of the reasons that the child is not provided with special care and protection. The law provides that the child should be protected in special circumstances (under section 19 of POCSO (2012) until the case is decided upon, but since the delay in the proceedings is an issue in the Indian judiciary, it is not certain how long the case might be adjudicated. The proceeding can be completed in six months or in six years, and the child cannot be kept in shelter homes for that long a period, as he/she may feel isolated because they are away from their friends, family and loved ones (Business Standard 2020).

The other issue which is related to the courts is the low conviction rate in the POCSO (2012) cases relative to other crimes. A majority of cases end up in acquittal. Only 18.49 percent of the total cases under POCSO (India, Protection of Children from Sexual Offences 2012) resulted in convictions in 2016 (Business Standard 2020). Major reasons for this include the victim turning hostile (HAQ Centre 2017) the prosecution failing to prove the case, and differences between the statement made in court and the complaint recorded by the police officer. In a case study conducted by National Law School Bangalore (2018), in some major states of India, the victim turned hostile during trials at the following rates: Karnataka (94\%), Maharashtra (47\%), Delhi (67.5\%), Assam (33\%) and Andhra Pradesh $(77 \%)$ (Kaur et al. 2019). The reasons for such hostility are both procedural aspects and social pressure on the child. The law directs the court to hold proceedings in such a way that the victim never comes into contact with the accused and provides for a seperate waiting room for the child while the accused is being questioned or examined. Due to a shortage of such facilities, the child is often present in the court premises, which may affect his/her decision making and testimony (Kaur et al. 2019; Bhattacharya and Kundu 2018). In the cases where the accused is a family member, we see some of the lowest conviction rates, since the child is living in the same household. The victim is pressured to change his/her statement in the court, resulting in an acquittal for the accused.

Media reports indicate that $99.1 \%$ of the cases of sexual assault go unreported in India (Bhattacharya and Kundu 2018) where talking about sex or sex-related topics is one of the biggest taboos. Sex education in schools rarely occurs. Children are not taught about what can amount to sexual assault. This means they may not know that what is happening with them is wrong. Equally, it can mean that the family is not open to receiving disclosures and not be prepared to manage the impact, including the shame and stigma that follows.

Incestuous rape has been shown to be committed by the father or stepfather of a female child in the majority of the reported cases (Seto et al. 2015), but older brothers or cousins are also often the perpetrators (Yates 2017). India is a patriarchal society, which results in significant gender disparities (Ghani et al. 2012) where even the male victims of CSA may receive better treatment if there is disclosure (Subramaniyan et al. 2017). 


\subsection{Indian Penal Code}

India is reported to be gaining the dubious reputation of being one of the highest risk countries for the sexual assault of women (India, Indian Penal Code 1860). In 2019, every day, 88 rape cases were reported to the police, out of which $98 \%$ of the rapes were committed by family members or close acquaintances (Bixler 1983). Incest has not been described as a separate offence for a child or adult woman.

Indian society does not believe that a woman can be sexually assaulted by a family member, but the data reported by NCRB in its annual report a different story (NCRB 2010, 2018 , 2019). In four years (2016-2019), a woman was more likely to be a victim of sexual assault by a family member then a child (Figure 2).

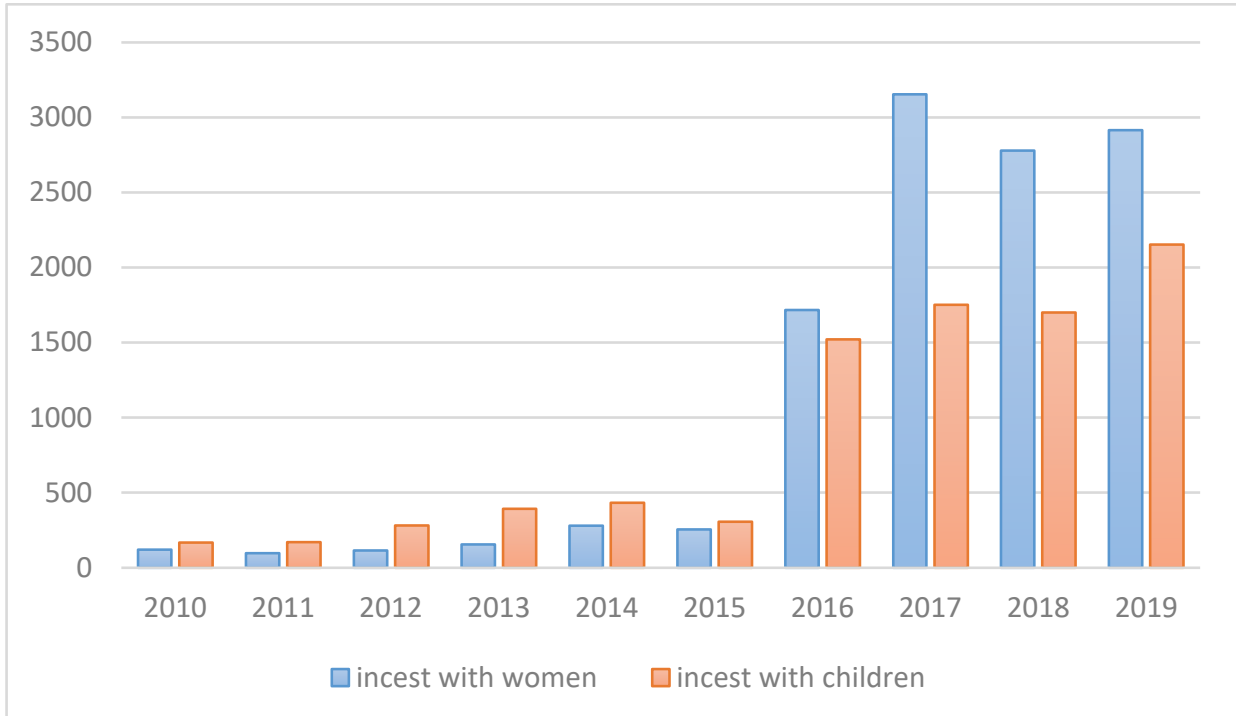

Figure 2. Reported incest cases against woman and children the data from 2016 for children is under POCSO (India, Protection of Children from Sexual Offences 2012).

Section 376 (2)(f) of the Indian Penal Code (1860) states that if a relative commits the rape of a woman, they shall be punished with rigorous imprisonment for no less than ten years, but which may be extended to imprisonment for life, and shall also be liable for a fine.

This section is the only one that deals with the sexual assault of women by a family member. It falls short as it does not describe who shall be deemed as a relative in the eye of law. The POCSO (India, Protection of Children from Sexual Offences 2012) makes a clear distinction when describing relatives as someone who is related to the victim by blood, marriage or adoption in its definition of aggravated penetrative sex and aggravated sexual assault.

CSA is underreported (Lemaigre et al. 2017). The scant literature and data in incestuous rapes suggest that this aspect of CSA may well be the most under-reported crime. The abuser is known to the victim and in a position to dominate and control their interaction with the world (Subramaniyan et al. 2017).

The Indian Penal Code (1860) has many legal gaps in providing protection against incestuous rape. A male victim is provided with no protection in rape cases, as Indian society deems that a male cannot be raped. POCSO (India, Protection of Children from Sexual Offences 2012) being the only gender-neutral law, provides protection to both a male and female child, but as soon as the male child reaches the age of consent, he is not protected by any law. The Justice Verma Committee (Verma et al. 2013) recommended that the Central Government substitute the term rape with sexual assault and make the offence gender-neutral. The government did not act upon this recommendation. 
In 2018, a Public Interest Litigation was submitted to the HC of Delhi alleging that the law was against Article 14 and Article 15 of the Constitution of India (1950). The Central Government filed an affidavit and told the $\mathrm{HC}$ to leave the definition of rape under the Indian Penal Code (1860) unchanged. The affidavit submitted by the Ministry of Home Affairs claimed that "This section was enacted to safeguard and control the increasing level of sexual offences against women in the country". The HC ultimately left the definition alone.

\subsection{Efforts at Reform}

As noted, the Central Government has avoided making rape gender-neutral, hence providing no protection to male victims against sexual abuse. There have been attempts made to pass gender-neutral bills against incestuous rape.

The Incest Offences Bill (2009) was introduced in the upper house of the Indian Parliament, Rajya Sabha on 31 July 2009. The bill criminalized sexual intercourse between a person and a close family member. Incest was made punishable with rigorous imprisonment for no less than ten years, but when the incest was committed with a child below the age of eighteen, the offender was to be punished with life imprisonment.

The Incest and Sexual Abuse in Family (Offences) Bill (2010) was introduced in the Rajya Sabha on 25 February 2011. The bill was presented with the aim to define offences related to incest and sexual abuse in a family and to establish a special procedure for its punishment. The bill prescribed rigorous imprisonment for a term of life and in cases when the victim of incest was a minor, then the offender was to be punished by death. The bill also provided for the establishment of special courts with a women magistrate to deal with incest cases.

A private member bill, The Incest Offences Bill (2012) was introduced in the Rajya Sabha in 2012. The bill was presented with an aim to provide for the punishment of the offence of incest. The bill criminalized sexual intercourse or sexual exploitation between two members of a family. The punishment for incest was similar to the bill of The Incest Offences Bill (2009).

The Incest Offences and Sexual Abuse of Females in Family (Prevention) Bill (2020) was introduced in the Rajya Sabha on 13 March 2020. The bill was introduced with an aim of defining the offence of incest and sexual abuse of women in the family. The bill only aimed to protect females from incestuous sexual acts in a family. The punishment prescribed by the bill is similar to that of The Incest and Sexual Abuse in Family (Offences) Bill (2010).

All four bills were not passed by the parliament. One of the interesting points to notice about all the bills is the statement of objects and reasons for each bill. They noted that, at the time, there were no laws against incest, but the incidents of incest in the family were increasing. They also mentioned the biggest reason that incest still exists in India and goes unnoticed is that society is in denial about the occurrence of incest and sexual abuse in the household by family members. They mentioned that courts let the offenders off without any punishment because there is no written law creating it as a separate offence.

The bills had their own deficiencies. They failed to provide special care and protection to the victim of incest. Provisions such as compulsory counselling for the victim, proper medical examination, shelter homes for the victim, maintenance for survival for an adult victim and special provision related to a child victim's education should have been included in the bills.

\section{Conclusions and Recommendations}

In this paper, we have shown that incest in India is under researched. Furthermore, it is not separated out as its own area of focus, but is integrated with the general child sexual abuse literature. This makes it difficult to focus upon the problem and to ensure that the social work and legal systems realise the need for intervention. CSA has been documented as an extensive area of concern (Choudhry et al. 2018), and incest deserves this energy as well. 
As we have shown, incest also needs to be an area of legislative attention which can, in turn, act as a fulcrum to action at both the preventative and response levels. Laws prohibiting behaviours are ways to gain societal attention.

If things are going to change, then there is an urgency to begin with these vital steps:

1. Laws must be explicit in the prohibition of incest, making them enforceable. The laws must also be comprehensive, both in the scope of defining what is included in the offence of incest, as well as including the full range of populations to be included. The efforts at reform, unsuccessful thus far, need to be revitalized;

2. There must be a widespread campaign in society to fully endorse the invalidity of incest in all of its various forms;

3. There must be truly accessible means to report the offence. This means well-trained police able to support a victim throughout the reporting and investigation phases right through the prosecution process. Female officers are important in facilitating reports by women and children;

4. There is a parallel need for systems to support children and families where incest has occurred;

5. Justice must be timely. The pressure on a victim to wait for long periods for a case to make its way from complaint to trial is an injustice for the victims; and

6. A robust child protection system is needed to support cases where a child is the victim.

The legal maxim "justice delayed is justice denied" has often been quoted. The legal system should embrace how challenging it is for a victim to come forward. However, if a society minimizes or denies that incest is a major problem, then victims are actively discouraged from reporting it, furthering the harm done by the original abuse. In essence, it says that the offence does not exist, such that society and its legal systems do not really care. It is the invalidation of the experience of the victim.

Indeed, we might argue that systems that are unwilling to act when a case is reported are, in fact, offering, at the very least, benign consent for incest to occur. Police, prosecutors and others involved who act in this way should be liable for failing to protect the victims.

The case of M.O Shamsudhin v. the State of Kerala (1995) is one of the rare cases which mention incest, in which Justice Bose observed that incest being committed in secret can never be brought to justice. The judgement in itself states that because incest is committed in secret or the private setting of home, it mostly goes unreported, and hence the victim is rarely provided with justice.

Our review indicates there is no cohesive way in which incest is managed. We have shown some efforts focused on the sexual abuse of children and some efforts focused on the sexual assault of women. However, no focused effort is apparent that addresses incest as a familial problem that requires a concerted plan to address. India is not alone in this problem. Many countries fail to have targeted ways to bring this form of family violence under control.

Incest goes against everything family stands for, which includes protection, nurturing, relationships and a place that grounds people in society. The victim of incestuous sexual assault is deeply shaken, faith in the safety of family is lost and the victim endures mental and physical distress. There is ongoing fear that that incestuous rape will occur repeatedly, putting the victim in continuous harm. The very people who should be there to protect are not fulfilling this role, meaning the victim has no one to turn to and usually ends up suffering their whole life. The effect of incestuous rape is similar to rape by an unknown person, if not worse, because the whole belief system of a person is shaken and torn apart.

Our work shows that there is a dramatic dearth of information specific to incest. We suggest that research needs to break apart CSA to develop a greater understanding about the dynamics and risks associated with incest. Better knowledge has the potential to enhance prevention, intervention, repair as well as to strengthen legal interventions. 


\section{Limitations}

This work is limited by the narrow scope of the literature search. The results are sparse. This highlights the need for more research, and knowledge requires expansion. Future work will need to develop insights focused specifically upon incest as a separate category from CSA. The work may also need to consider that incest itself has subcategories that need probing inquiry, such as those that are based upon the specific perpetrator-victim relationships.

Author Contributions: Conceptualization, R.S.; methodology, P.C.; investigation, R.S.; writ-ingoriginal draft, R.S.; writing-review and editing, P.C.; supervision, P.C.; project admin-istration, P.C. Please turn to the CRediT taxonomy for the term explanation. Authorship must be limited to those who have contributed substantially to the work reported. All authors have read and agreed to the published version of the manuscript.

Funding: This research received no external funding.

Conflicts of Interest: The authors declare no conflict of interest.

\section{References}

Alaggia, Ramona, Delphine Collin-Vézina, and Russan Lateet. 2019. Facilitators and barriers to child sexual abuse disclosurers: A research update (2000-2016). Trauma, Violence and Abuse 20: 260-81. [CrossRef]

Ardulov, Victor, Madelyn Mendelen, Manoj Kumar, Neha Anand, Shanna Williams, Thomas Lyon, and Shrinkath Narayann. 2018. Multimodal interaction modelling of child forensic interviewing. Paper presented at 20th ACM International Conference on Multimodal Interaction, Boulder, CO, USA, October 16-20; pp. 179-85. [CrossRef]

Azzopardi, Corry, Rachel Eirich, Christina L. Rash, Sarah MacDonald, and Sheri Madigan. 2019. A meta-analysis of the prevalence of child sexual abuse disclosure in forensic settings. Child Abuse and Neglect 93: 291-304. [CrossRef]

Ballantine, Margaret.W. 2012. Sibling incest dynamics: Therapeutic themes and clinical challenges. Clinical Social Work 40: 56-65. [CrossRef]

National Law School Bangalore. 2018. Implementation Of The POCSO Act, 2012 by Special Courts: Challenges and Issues. CCL.NLS.AC.IN. Available online: https:/ /ccl.nls.ac.in/wp-content/uploads/2017/01/Implementation-of-the-POCSO-Act-2012-by-speicalcourts-challenges-and-issues-1.pdf (accessed on 15 March 2021).

Bhattacharya, Pramit, and Tadit Kundu. 2018. 99\% Cases of Sexual Assaults Go Unreported, Govt Data Shows. Mint. April 24. Available online: https://www.livemint.com/Politics/AV3sIKoEBAGZozALMX8THK/99-cases-of-sexual-assaults-gounreported-govt-data-shows.html (accessed on 5 March 2021).

Bittles, Alan H. 2012. Consanguinity in Context. Cambridge: Cambridge University Press.

Bixler, Ray H. 1983. The multiple meaning of "incest". Journal of Sex Research 19: 197-201. [CrossRef]

Business Standard. 2020. Over 240,000 Rape and POCSO Cases Pending in Courts: Govt Tells LS. March 5. Available online: https:/ / www.business-standard.com/article/news-ani/over-2-4-lakh-cases-relating-to-rape-and-pocso-pending-in-courtsacross-country-says-govt-120030500162_1.html (accessed on 6 March 2021).

Carson, David K., Jennifer M. Foster, and Nishi Tripathi. 2013. Child sexual abuse in India: Current issues and research. Psychological Studies 58: 318-25. [CrossRef]

Choudhry, Vikas, Radhika Dayal, Divya Pillai, Ameeta S. Kalokhe, Klaus Beier, and Vikram Patel. 2018. Child sexual abuse in India: A systematic review. PLoS ONE 13: e0205086. [CrossRef] [PubMed]

Clayton, Estelle, Christine Jones, Jon Brown, and Julie Taylor. 2018. The aetiology of child sexual abuse: A critical review of the empirical evidence. Child Abuse Review 27: 181-97. [CrossRef]

Constitution of India. 1950. Available online: https:/ /legislative.gov.in/sites/default/files/COI_1.pdf (accessed on 2 March 2021).

Cromer, Lisa D., and Rachel E. Goldsmith. 2010. Child sexual abuse myths: Attitudes, beliefs, and individual differences. Journal of Child Sexual Abuse 19: 618-47. [CrossRef] [PubMed]

Das, Ria. 2020. Lockdown Horror: Cases of Fathers Raping Daughters across India. SheThePeople TV. June 4. Available online: https: / www.shethepeople.tv/home-top-video/lockdown-horror-cases-of-fathers-raping-daughters-across-india/ (accessed on 15 March 2021).

Doshi, Vidhi. 2018. Why India's Modern Women Say It's a 'Burden' to Be Female. March 12. Available online: https://www. washingtonpost.com/news/worldviews/wp/2018/03/12/why-indias-modern-women-say-its-a-burden-to-be-female/ (accessed on 15 March 2021).

Gekoski, Anna, Julia C. Davidson, and Mrianda A. H. Horvath. 2016. The prevalence, nature, and impact of intrafamilial child sexual abuse: Findings from a rapid evidence assessment. Journal of Criminological Research, Policy and Practice 2: 231-43. [CrossRef]

Ghani, Ejaz, Willaim R. Kerr, and Stephen D. O'Connell. 2012. What Explains Big Gender Disparities in India?Local Industrial Structures and Female Entrepreneurship. Washington, DC: The World Bank. 
Green, Stuart P. 2019. Incest. In The Palgrave Handbook of Applied Ethics and the Criminal Law. Edited by Larry Alexander and Kimberly.K. Ferzan. London: Palgrave-MacMillan, pp. 337-57.

Greydannus, Donald E., and Joav Merrick. 2017. Incest: Child sexual abuse within the family. International Journal of Child and Adolescent Health 10: 295-304.

HAQ Centre. 2017. Implementation of the Pocso Act. Available online: https://haqcrc.org/wp-content/uploads/2018/02/ implementation-of-the-pocso-act-delhi-mumbai-study-final.pdf (accessed on 2 March 2021).

Human Rights Watch. 2013. Breaking the Silence: Child Sexual Abuse in India. New York: Human Rights Watch.

Indian Penal Code. 1860. The Government of India. Available online: https://legislative.gov.in/sites/default/files/A1860-45.pdf (accessed on 15 March 2021).

India, Protection of Children from Sexual Offences. 2012. Government of India. Available online: http://legislative.gov.in/sites/ default/files/The\%20Protection\%20of\%20Children\%20from\%20Sexual\%20Offences\%20Act\%2C\%202012_0.pdf (accessed on 15 March 2021).

India, Christian Marriage Act. 1872. The Government of India. Available online: http://home.kar.nic.in/download_files/Passport/ The_Indian_Christian_Marriage_Act1872.pdf (accessed on 15 March 2021).

India, Hindu Marriage Act. 1955. The Government of India. Available online: https://highcourtchd.gov.in/hclscc/subpages/pdf_files/ 4.pdf (accessed on 2 March 2021).

India, The Muslim Personal Law (Shariat) Application Act. 1937. The Government of India. Available online: https:/ /www.indiacode.nic. in/bitstream/123456789/2303/1/A1937-26.pdf (accessed on 20 March 2021).

India, Special Marriage Act. 1954. The Government of India. Available online: https://legislative.gov.in/sites/default/ files /A1954-43 1.pdf (accessed on 2 March 2021).

Irudayam, Aloysius, Jayshree.P. Mangubhai, and Joel G. Lee. 2011. Dalit Women Speak Out: Caste, Class and Gender Violence in India. New Delhi: Zubaan Books.

Jeaash, Najila M. 2020. A critical look at U.S. law approach regarding consensual adult incest. Alostath. Available online: https: / / uotpa.org.ly/alostath/index.php/alostath/article/view/193 (accessed on 5 March 2021).

Juyal, Deepak, Ajay Setia, Ashutosh Sayana, Adarsh Kumar, Vyas K. Rathaur, and Benu Dhawan. 2017. Lack of special courts under protection of children from sexual offences act: A structural deficit. Journal of Family Medicine E Primary Care 6: 881-82. [CrossRef]

Kacker, Loveleen, and Pravesh Kumar. 2008. Child abuse in India. In World Perspectives on Child Abuse, 8th ed. Edited by Deborah Daro. Chicago: International Society for Prevention of Child Abuse and Neglect (ISPCAN), pp. 98-100.

Kaur, Suminder, Simarpreet Kaur, and Kajal Varshney. 2019. Recent trends in child rape crisis in Delhi (India): A forensic overview. Forensic Science International: Reports 1. [CrossRef]

Kloppen, Kathrine, Siren Haugland, Carl Göran Svedin, Magne Mæhle, and Kyrre Breivik. 2016. Prevalence of child sexual abuse in the Nordic countries: A literature review. Journal of Child Sexual Abuse 25: 37-55. [CrossRef] [PubMed]

Kluft, Richard P. 2011. Ramifications of Incest. Psychiatric Times. Available online: https://www.psychiatrictimes.com/view/ ramifications-incest (accessed on 9 March 2021).

Lemaigre, Charlotte, Emily P. Taylor, and Claire Gittoes. 2017. Barriers and facilitator to disclosure of sexual abuse in childhood and adolescence: A systematic review. Child Abuse and Neglect 70: 89-52. [CrossRef] [PubMed]

Lieberman, Debra, and Adam Smith. 2012. It's all relative: Sexual aversions and moral judgments regarding sex among siblings. Current Directions in Psychological Science 21: 243-47. [CrossRef]

Ministry of Home Affairs. 2020. Mandatory Action by Police in Cases of Crime against Women. October 9. Available online: https:/ / www.mha.gov.in/sites/default/files/Womensafety_10102020.pdf (accessed on 17 March 2021).

Moher, David, Alessandro Liberati, Jennifer Tetzlaff, Douglas G. Altman, and The PRISMA Group. 2009. Preferred Reporting Items for Systematic Reviews and Meta-Analyses: The PRISMA Statement. PLoS Medicine 6: e1000097. [CrossRef]

Namhata, Shinjinee. 2020. Incest in India: The need to criminalize It. International Journal of Advanced Legal Research. Available online: https://www.ijalr.in/2020/08/incest-in-india-need-to-criminalize-it.html (accessed on 1 March 2021).

NCRB. 2018. Annual Report on Crime in India. Available online: https:/ /ncrb.gov.in/en/crime-india-2018 (accessed on 25 February 2021).

NCRB. 2019. Report on Crime in India. Available online: https://ncrb.gov.in/sites/default/files/crime_in_india_table_additional_ table_chapter_reports/Table\%204A.10_1.pdf (accessed on 24 February 2021).

NCRB. 2010. Annual Report on Crime in India. Available online: https://ncrb.gov.in/sites/default/files/crime_in_india_table_ additional_table_chapter_reports/Table\%205.3_2010.pdf (accessed on 5 March 2021).

Pandey, Anubhav. 2017. Legal Status of Incest in India. May 10. Available online: https://blog.ipleaders.in/incest-legality/ (accessed on 5 March 2021).

Poddar, Shuvabrata, and Urbi Mukherjee. 2020. Ascending Child Sexual Abuse Statistics in India during COVID-19 Lockdown: A Darker Reality and Alarming Mental Health Concerns. Indian Journal of Psychological Medicine 42: 493-94. [CrossRef]

Porta, Miquel, and John M. Last. 2018. A Dictionary of Public Health. Oxford: Oxford University Press.

Putnam, Frank W. 2003. Ten-year research update review: Child sexual abuse. Journal of the American Academy of Child E Adolescent Psychiatry 42: 269-78. [CrossRef]

R v G.R. 2005. Available online: https://www.canlii.org/en/ca/scc/doc/2005/2005scc45/2005scc45.html (accessed on 28 February 2021). 
Ravi, Reethu. 2020. Awareness: 90\% of Abusers Are Known to Victim: How This NGO Is Prepping Families to Fight Child Sexual Abuse. April 30. Available online: https:/ / thelogicalindian.com/exclusive/lockdown-child-sexual-abuse-cases-20852 (accessed on 6 March 2021).

Sagarin, Edward. 1977. Deviance and Social Change. Thousand Oaks: Sage.

Satish. 2020. The State of Maharashtra (Criminal Appeal no. 161 of 2020). Available online: https://www.livelaw.in/pdf_upload/ pressing-a-childs-breast-without-skin-to-skin-contact-does-not-amount-to-sexual-assault-under-pocso-act-bombay-highcourt-388064.pdf (accessed on 28 February 2021).

Seth, Rajeev, and R. N. Srivastava. 2017. Child sexual abuse: Management and prevention, and Protection of Children from Sexual Offences (POCSO) Act. Indian Paediatrics 54: 949-53. [CrossRef] [PubMed]

Seto, Michael C., Kelly M. Babchishin, Leskeigh. E. Pullman, and Ian V. McPhail. 2015. The puzzle of intrafamilial child sexual abuse: A meta-analysis comparing intrafamilial and extrafamilial offenders with child victims. Clinical Psychology Review 39: 42-57. [CrossRef]

Sharangpani, Mukta. 2018. The safe Natal home and other myths: Sibling violence and incest in India, South Asia. Journal of South Asian Studies 41: 535-50. [CrossRef]

Stoltenborgh, Marije, Marinus H. van IJzendoorn, Eveline M. Euser, and Marian J. Bakermans-Kranenburg. 2011. A global perspective on child sexual abuse: Meta-analysis of prevalence around the world. Child Maltreatment 16: 79-101. [CrossRef] [PubMed]

Subramaniyan, Vyajanthi, Praveen Reddy, Girish Chandra, Chandrika Rao, and T.S. Sathyanarayan Rao. 2017. Silence of male child sexual abuse in India: Qualitative analysis of barriers for seeking psychiatric help in a multidisciplinary unit in a general hospital. Indian Journal of Psychiatry 59: 202-7. [CrossRef]

The Incest and Sexual Abuse in Family (Offences) Bill. 2010. Available online: http:/ /164.100.47.4/billstexts/rsbilltexts/AsIntroduced/ incest.pdf (accessed on 3 March 2021).

The Incest Offences and Sexual Abuse of Females in Family (Prevention) Bill. 2020. Available online: http://164.100.47.4/BillsTexts/ RSBillTexts/asintroduced/Incest-E-13320.pdf (accessed on 5 March 2021).

The Incest Offences Bill. 2009. Available online: http:/ /164.100.47.4/billstexts/rsbilltexts/AsIntroduced/incest\%20X\%20of\%2009.pdf (accessed on 5 March 2021).

The Incest Offences Bill. 2012. Available online: http://164.100.47.4/billstexts/lsbilltexts/asintroduced/4119LS.pdf (accessed on 5 March 2021).

Tillman, Shaquita, Thema Bryant-Davis, Kimberly Smith, and Alison Marks. 2010. Shattering silence: Exploring barriers to disclosure for African American sexual assault survivors. Trauma, Violence, \& Abuse 11: 59-70. [CrossRef]

Tiwary, Akshita. 2020. The need to criminalize juvenile incest in India. In The Criminal Law Blog. Jodhpur: National Law University, Available online: https:/ / criminallawstudiesnluj.wordpress.com/2020/07/21/the-need-to-criminalize-juvenile-incest-in-india / (accessed on 5 March 2021).

Tripathi, Rahul. 2020. Women Police Personnel Constitute a Meagre 8.98\% of Police Force across India: BPR\&D. The Economic Times. January 30. Available online: https:/ / economictimes.indiatimes.com/news/defence/women-police-personnel-constitute-ameagre-8-98-of-police-force-across-india-bprd/articleshow /73736033.cms?from=mdr (accessed on 5 March 2021).

United Nations Conventions on the Right of the Child. 1990. Available online: https://treaties.un.org/pages/ViewDetails.aspx?src=IND\& mtdsg_no=IV-11\&chapter=4\&lang=en (accessed on 5 February 2021).

Verma, Jagdish Shara, Leila Seth, and Gopal Subramanium. 2013. Report of the Committee on Amendments to Criminal Law. New Delhi: Justice Committee on Amendaments to Criminal Law, Available online: https:/ / www.prsindia.org/uploads/media/Justice\%20 verma\%20committee/js\%20verma\%20committe\%20report.pdf (accessed on 28 February 2021).

World Health Organization (WHO). 2017. Responding to Children and Adolescents Who Have Been Sexually Abused: Clinical Guidelines. Geneva: World Health Organization.

Yates, Peter. 2017. Sibling sexual abuse: Why don't we talk about it? Journal of Clinical Nursing 26: 2482-94. [CrossRef]

Yildirim, Ali, Erdal Ozer, Hasan Bozkurt, Sait Ozsoy, Ozgur Enginyurt, Durmus Evcuman, Riza Yilmaz, and Yunus E. Kuyucu. 2014. Evaluation of social and demographic characteristics of incest cases in a university hospital in Turkey. Medical Science Monitor: International Medical Journal of Experimental and Clinical Research 20: 693-97. [CrossRef] 